\title{
PENINGKATAN PERILAKU PROFESIONALISME PEKERJA MENGHADAPI TANTANGAN GLOBALISASI PADA ABAD 21
}

\author{
Menara Simanjuntak \\ Jurusan Manajemen, Fakultas Ekonomi dan Bisnis, Universitas Bina Nusantara, \\ Jln. K.H. Syahdan No. 9, Palmerah, Jakarta Barat 11480 \\ menara0110@yahoo.com
}

\begin{abstract}
The employee professionalism and behavior development are important issues related to their job performance, job satisfaction, and future career. The future of human resource' needs are determined by the organization's mission, goal, and strategiy. This research used literature review and other study sources related to the topic using descriptive analysis method. The view study shows that demand for employees are result of demand for the organization's products or services, more productivities, to reach high performances of revenue and profit. Based on that, management can attempt to establish the number of mix employees needed attempt to reach it. Company's compensation and benefit program didn't allow for giving rises to employee who stayed in the same position. The only way for management to reward the top performers was to give them a bonus or promote them to another position. It is more important to adjust the individual professionalism and behavior with the organizational culture and behavior through employee training and course program. The best opportunity for an employee is to catch on job at or to be a manager in another country to get the different experience than their host country as a global attitude. This is a global-oriented view that focuses on using the best approaches.
\end{abstract}

Keywords: employee professionalism, behavior development, productivity, job performance, job satisfaction

\begin{abstract}
ABSTRAK
Pengembangan profesionalisme dan perilaku karyawan merupakan isu penting terkait dengan kinerja, kepuasan kerja, dan karir masa depan mereka. Kebutuhan sumber daya manusia masa depan ditentukan oleh misi, tujuan dan strategi organisasi. Penelitian ini menggunakan studi pustaka dan sumber lain-lain untuk mempelajari yang terkait dengan topic, menggunakan metode analisis deskriptif. Studi tampilan menunjukkan bahwa permintaan untuk karyawan adalah hasil permintaan untuk produk atau layanan organisasi, produktivitas lebih, untuk mencapai kinerja tinggi pendapatan dan keuntungan, dan pada itu manajemen mencoba untuk menetapkan jumlah karyawan yang diperlukan untuk mencapai itu. Kompensasi dan program manfaat perusahaan itu tidak memungkinkan untuk memberikan kenaikan untuk karyawan yang tetap di posisi yang sama. Satu-satunya cara bagi manajemen untuk member hadiah untuk kinerja terbaik adalah untuk memberi mereka bonus atau mempromosikan mereka ke posisi lain. Lebih penting untuk menyesuaikan profesionalisme dan perilaku individu dengan budaya dan perilaku organisasi melalui pelatihan dan program kursus karyawan. Kesempatan terbaik untuk karyawan ialah mendapat pekerjaan atau menjadi manajer di negara lain untuk mendapatkan pengalaman yang berbeda dari negara asal sebagai sikap global. Ini adalah pandangan berorientasi global yang memfokuskan pada penggunaan pendekatan yang terbaik.
\end{abstract}

Kata kunci: profesionalisme karyawan, pengembangan perilaku, produktivitas, prestasi kerja, kepuasan kerja 


\section{PENDAHULUAN}

Tantangan angkatan kerja baru sekarang yang sudah bekerja maupun yang belum mendapatkan pekerjaan serta angkatan kerja di masa-masa mendatang dalam kurun abad ke-21 ditandai dengan tututan profesionalisme yang semakin meningkat. Persaingan mendapatkan pekerjaan, dan persaingan di tempat kerja semakin sengit dan menantang. Persaingan mendapatkan pekerjaan di negara maju (developed country) juga semakin ketat karena pertumbuhan angkatan kerja baru ditambah para pendatang serta semakin bertambahnya pekerja di atas usia 60 tahun yang masih mempertahankan pekerjaannya. Pada negara sedang membangun (developping country), apalagi di negara yang masih terbelakang (under-development country), selain pertumbuhan angkatan kerjanya rata-rata di atas 3\% per tahun ditambah dengan angkatan kerja yang tidak terserap (menganggur) pada beberapa tahun sebelumnya disertai lambatnya pertumbuhan lapangan kerja baru, membuat pertarungan semakin luar biasa. Kajian ini hanya menguraikan secara deskriptif tentang tantangan bagi mereka yang sedang bekerja menghadapi era globalisasi abad ke-21 yang menuntut para pekerja semakin profesional. Pekerja profesional adalah pekerja yang memiliki ketrampilan dan bekerja sesuai dengan ketrampilan yang dimiliki selalu dianggap yang memiliki penghasilan diatas rata-rata. Sedangkan mereka yang tidak memiliki ketrampilan dan bekerja hanya mengandalkan kesediaan untuk mengerjakan sesuatu pekerjaan yang memerlukan ketrampilan sederhana, yang biasanya memperoleh gaji/upah di bawah rata-rata atau rendah. Indonesia sebagai negara berpenduduk empat besar di dunia juga diharapkan mendorong para pekerja profesional untuk mendapatkan peluang bekerja di luar negeri untuk menimba pengalaman yang berbeda. Tantangan para pekerja dewasa ini dan di masa mendatang dalam menghadapi dan melaksanakan pekerjaannya serta dalam pengembangan karir dipengaruhi oleh faktor-faktor individual, kesempatan (opportunity), motivasi, ketrampilan dan prestasi, kompensasi dan tunjangan, kepuasan kerja, budaya organisasi, perkembangan teknologi, ekonomi suatu negara, persaingan global, dan yang di dalamnya faktor silang budaya.

Pentingnya analisis ini sebagai informasi dan rekomendasi bagi para pekerja pada umumnya agar tidak memilih dan bersikap berbeda dan mampu menyesuaikan diri terhadap keadaan perubahan lingkungan pekerjaan masa kini maupun kecenderungan masa mendatang. Dengan demikian, yang menjadi pertanyaan dalam kajian deskriptif ini adalah "Bagaimana upaya peningkatan perilaku profesionalisme pekerja dan peluang menghadapi tantangan globalisasi pada abad ke-21?”.

Memasuki abad ke-21, hampir semua aspek lingkungan kehidupan berubah dengan akselesasi yang demikian cepat sehingga profesionalisme pekerja juga paling tidak harus harus sejajar dan harus mampu mengantisipasi kecenderungan ke depan. Profesionalisme tidak lagi sekedar ahli dalam bidang pekerjaan yang ditekuninya, namun seseorang juga perlu kembali memahami dirinya sendiri dan sekitar lingkungan bidang pekerjaannya secara keseluruhan serta memahami nilai arah tujuan yang ingin dicapai dalam kehidupannya maupun tujuan, misi dan strategi organisasi di mana seseorang bekerja.

Peningkatan perilaku profesionalisme pekerja dilatarbelakangi oleh perilaku individu dalam organisasi. Pemahaman diri pekerja pada umumnya memiliki keyakinan dasar, tujuan, nilai serta sikap yang merupakan bagian dari kepribadian pekerja. Menyangkut kepribadian ini merupakan bagian dari yang diamati dalam proses seleksi pekerja pada saat awal sebelum diterima bekerja, kemudian pada saat bekerja untuk menentukan pembinaan dan pengembangan karir pekerja tersebut sesuai minat dan keahliannya.

\section{Perilaku Individu Pekerja}

Jikalau kita membicarakan profesionalisme pekerja, tidak terlepas dari sumber perilaku individu pekerja itu sendiri, antara lain meliputi nilai, sikap, dan kepribadian yang dimiliki seseorang 
pekerja, selain dari latar belakang karakteristik individu yang bersangkutan seperti jenis kelamin, umur, pendidikan, status, pengalaman dan sebagainya. Kepribadian manusia pertama kali diamati oleh Sigmund Freud tentang struktur kepribadian manusia, dan kepribadian pekerja oleh Gordon Allport lebih dari 70 tahun lalu. Banyak penelitian lanjutan lainnya mengamati pekerja seperti Bouchard, $d k k$ (1990:223) menyatakan bahwa "organisasi dinamis di dalam masing-masing sistem psikofisik yang menentukan penyesuaian unik terhadap lingkungannya”, kemudian diredefinisikan sebagai "total jumlah cara-cara dalam mana seorang individu bereaksi dan berinteraksi dengan orang-orang lain. Jika kita mengetahui bahwa ada seseorang dianggap berpembawaan halus, tenang, keras, agresif, ambisius, terbuka, loyal, berjiwa sosial adalah menjelaskan tentang kepribadian seseorang.

Terkait dengan kepribadian tersebut, Connor dan Becker (1991:67) mengatakan bahwa pekerja dalam kehidupan ini memiliki keyakinan dasar seperti lebih menyukai sesuatu daripada yang lain, apa yang benar, baik atau diinginkan, apa yang seharusnya, dan tidak seharusnya. Kemudian, bahwa para pekerja juga memiliki nilai yang ingin dicapai pada akhir eksistensinya sebagai rumusan penelitian yang dikenal sebagai Survei Rokeah (1989:775). Rokeah menyatakan bahwa nilai yang dianut manusia sekitar nilai terminal (tujuan), yaitu eksistensi hidup seseorang pekerja yang diinginkan seperti keinginan makmur atau kaya, berprestasi, harmoni, kebahagiaan, dihormati dan sebagainya. Untuk mencapai nilai terminal tersebut diperlukan nilai instrumental atau cara-cara mencapai tujuan tersebut seperti harus rajin belajar, kerja keras, hemat, jujur dan sebagainya.

Selanjutnya, kepribadian para pekerja yang dibedakan atas tempat kedudukan kendali menurut Spector (1987:482) bahwa sebagian pekerja meyakini mereka menguasai nasibnya sendiri atau memiliki tempat kedudukan kendali internal (internal locus of control). Sebagian lagi pekerja menganggap bahwa kemujuran atau nasib mereka ditentukan oleh kekuatan dari luar, yang disebut tempat kedudukan kendali eksternal (external locus of control). Selanjutnya Brook, dkk (1988:145) menyimpulkan bahwa kepuasan kerja, keterlibatan kerja, dan komitmen organisasi didasari oleh sikap pekerja itu sendiri.

Sedangkan sikap (attitude) menurut Breckler (1984:1191) adalah pernyataan evaluatif mengenai objek, orang atau peristiwa, baik yang menguntungkan maupun tidak menguntungkan bagi dirinya. Secara umum, orang mengatakan "sikap dan perilaku". Padahal menurut Fishel (1998:91), yang dimaksud sebenarnya adalah ungkapan perasaan terhadap sesuatu, yang merupakan ungkapan biasa, namun belum mencakup 3 aspek sebagai berikut, yaitu komponen kognisi dari suatu sikap, dihubungkan dengan keyakinan, opini, pengetahuan atau informasi yang dimiliki seseorang, misalnya atas tindak-tanduk orang tertentu, atau mengetahui cara membuat sesuatu. Kognisi tersebut dapat mempengaruhi afeksi. Komponen afeksi dari suatu sikap adalah emosi atau perasaan , suara batin, dan kata hati adalah bagian dari sikap seperti menyukai atau tidak menyukai seseorang, atau merasa ingin melakukan atau tidak ingin melakukan sesuatu tindakan tertentu. Komponen perilaku dari suatu sikap dihubungkan dengan maksud dan tujuan untuk memperlakukan dengan cara yang pasti terhadap seseorang atau sesuatu, misalnya semakin dekat atau semakin jauh menjaga jarak, atau dengan sertamerta melakukan sesuatu tindakan atas sesuaru. Ketiga komponen tersebut secara sendiri-sendiri atau bersama-sama mempengaruhi sikap (attitude) seseorang.

Suatu hal yang perlu kita pahami bahwa perilaku organisasi sering digambarkan sebagai fenomena gunung es, hanya sebagian kecil kelihatan nampak nyata tapi sebagian besar tidak nyata. Perilaku organisasi menurut LePine, $d k k$ (2003:52) adalah suatu studi yang menyelidiki dampak perorangan, kelompok dan struktur pada perilaku dalam organisasi, dengan maksud menerapkan pengetahuan tersebut untuk memperbaiki keefektifan organisasi. Perilaku adalah tindakan dari orangorang, sedangkan perilaku organisasi dapat dikatakan secara singkat sebagai aksi dari orang-orang di lingkungan kerja. Perilaku organisasi diarahkan pada 2 bidang. Pertama, melihat perilaku individu dengan lebih banyak melihat aspek sosial psikologis. Bidang ini membahas antara lain sikap, kepribadian, persepsi, pembelajaran, dan motivasi. Namun, hal ini sulit dilakukan secara berdiri sendiri karena dominannya pekerja dalam susunan kelompok ataupun tim kerja. Kedua, perilaku 
organisasi memberikan perhatian terhadap perilaku kelompok, yang di dalamnya termasuk norma, peran, pengembangan tim, dan kepemimpinan dan konflik. Perilaku kelompok dapat diketahui dari penjumlahan tindakan-tindakan individu dari kelompok pekerja karena individu-individu dalam kelompok berperilaku berbeda dibanding ia bekerja sendiri.

Adapun tujuan perilaku organisasi adalah untuk menjelaskan, memperkirakan, dan mempengaruhi perilaku. Manajer bertugas mengelola perilaku para pekerja karena kita memahami bahwa manajer mendapatkan sesuatu hasil melalui kegiatan orang-orang lain. Untuk melakukan tugas tersebut, maka manajer juga perlu mengetahui dan menjelaskan mengapa seseorang berperilaku tertentu berbeda dengan orang lain, memperkirakan bagaimana para pekerja menunjukkan respon dalam berbagai tindakan yang diambil oleh manajer, dan apa pengaruhnya terhadap perilaku pekerja.

\section{Kepuasan Kerja}

Dalam memahami perilaku pekerja secara khusus, kita memberi perhatian tentang penjelasan, prakiraan, dan pengaruh. Ada 5 hal yang penting sekali menurut Keller (1997:539), diidentifikasi berupa kepuasan atas produktifitas pekerja, kehadiran, tingkat keluarnya pekerja, perilaku keanggotaan organisasi, dan kepuasan kerja. Produktivitas pekerja adalah pencapaian yang diukur dari efektifitas dan efisiensi. Manajer tentu ingin mengetahui hal-hal yang mempengaruhi efisiensi dan efektifitas dari setiap pekerja. Rendahnya ketidakhadiran (absenteism) adalah masalah yang sulit jika pekerja tidak hadir. Namun, secara total ketidakhadiran tidak mempengaruhi fungsi organisasi karena sebagian besar lainnya yang hadir dapat melaksanakan kegiatan organisasi. Rendahnya keluar dan masuknya karyawan (turnover) karena jika cukup besar dapat merugikan perusahaan karena biaya yang cukup besar diperlukan membayar pesangon, melakukan penarikan, seleksi, dan pelatihan.

Perilaku keanggotaan organisasional merupakan kebebasan perilaku dan tidak merupakan bagian dari persyaratan kerja formal para pekerja, tetapi dengan perilaku tersebut dapat meningkatkan efektifitas secara fungsional bagi organisasi. Misalnya, para pekerja saling tolong menolong, bekerja dalam tim, secara sukarela memperluas pekerjaannya, menemukan cara penyelesaian konflik, dan membuat suatu pernyataan yang konstruktif dalam suatu kelompok dan organisasi. Organisasi memerlukan orang-orang yang dapat melakukan lebih banyak pekerjaan daripada yang hanya mereka kerjakan dalam penugasan formal. Namun, tidak dapat dipungkiri bahwa selalu ada anggota organisasi yang tidak mencapai performa kinerja. Kepuasan kerja merujuk pada umumnya sikap individu terhadap dirinya maupun pekerjaannya. Meskipun kepuasan kerja adalah suatu sikap yang berbeda dengan perilaku, maka sikap yang demikianlah yang diharapkan oleh manajemen karena kepuasan kerja para pekerja akan cenderung menekuni pekerjaan dan tinggal bersama organisasi.

\section{Kemampuan Intelektual, Emosional dan Fisik}

Sejak tahun 70-an, di Indonesia mulai marak dilakukan psikotes. Selain kemampuan intelektual (Intellectual Questions - IQ) dan tes fisik kesehatan, juga diperbincangkan tes-tes lain seperti tes EQ dan SQ (Emotional Questions dan Spiritual Question) untuk berbagai kepentingan termasuk seperti dalam seleksi memasuki suatu organisasi/perusahaan maupun dalam pengembangan para pegawai/pekerja. Sedangkan pada umumnya tes tersebut ditujukan untuk memperoleh gambaran tentang kemampuan calon atau pekerja. Selanjutnya, yang penting diuraikan dalam kesempatan ini adalah kemampuan intelektual, fisik, dan emosional. Kemampuan intelektual adalah kemampuan yang diperlukan untuk menjalankan kegiatan mental. Uji IQ juga diberlakukan masuk perguruan tinggi dan pascasarjana. Menurut Crites-Fabrigal (1994:619), terdapat 7 dimensi yang paling sering dikumpulkan dalam menyusun kemampuan intelektual, yaitu kemahiran berhitung, pemahaman verbal, kesepatan perceptual, penalaran induktif, penalaran deduktif, visualisasi ruang, dan ingatan. 
Salah satu bidang penelitian tentang emosi menambah pengetahuan kita tentang kepribadian adalah intelijen emosional (emotional intelligent). Menurut Ashkanasy dan Hartel, (2002:365), bahwa yang bukan ketrampilan kognisi, kemampuan, dan kompetensi yang mempengaruhi kemampuan seseorang untuk berhasil dalam menanggulangi tuntutan lingkungan dan tekanan. Berikut ini susunan dari 5 dimensi dimaksud, yaitu (1) Kepedulian diri, merupakan kemampuan menjadi peduli terhadap apa yang dirasakan, (2) Manajemen diri, merupakan kemampuan untuk mengelola emosi kita sendiri, (3) Motivasi diri, merupakan kemampuan menghadapi dan mengatasi kemunduran dan kekeliruan, (4) Empati, merupakan kemampuan merasakan apa yang dirasakan orang lain, dan (5) Ketrampilan sosial, merupakan kemampuan meredam dan mengendalikan emosi orang lain.

Intelijen emosional ini telah menunjukkan hasil yang positif dihubungkan dengan performa kinerja pada seluruh tingkatan. Sementara itu, kemampuan intelektual memainkan peranan yang lebih besar dalam pekerjaan rumit dengan persyaratan pemprosesan informasi yang menuntut kemampuan jasmani (fisik). Kemampuan fisik menurut The American Society for Personal Administrator (1979L:90) adalah kemampuan yang diperlukan untuk melakukan tugas-tugas yang menuntut stamina, kecekatan, kekuatan, dan ketrampilan serupa, sebagaimana terlihat dalam Tabel 1 berikut ini.

Tabel 1 Sembilan Kemampuan Fisik Dasar

\begin{tabular}{|c|c|}
\hline \multicolumn{2}{|r|}{ Sembilan Kemampuan Fisik Dasar } \\
\hline Faktor-Faktor Kekuatan & \\
\hline 1. Kekuatan dinamis & $\begin{array}{l}\text { - Kemampuan untuk mengerahkan kemampuan otot secara } \\
\text { berulang-ulang sepanjang suatu kurun waktu. }\end{array}$ \\
\hline 2. Kekuatan tubuh & $\begin{array}{l}\text { - Kemampuan mengenakan kekuatan otot dengan menggunakan } \\
\text { otot-otor tubuh (terutama perut). }\end{array}$ \\
\hline 3. Kekuatan statik & • Kemampuan menggunakan kekuatan terhadap objek luar. \\
\hline 4. Kekuatan & $\begin{array}{l}\text { - Kemampuan menghabiskan suatu maksimum energi eksplosif } \\
\text { dalam satu atau sederetan tindakan eksplosif. }\end{array}$ \\
\hline \multicolumn{2}{|l|}{ Faktor-faktor Keluwesan } \\
\hline 5. Keluwesan ekstent & - Kemampuan menggerakkan otot tubuh dan meregang \\
\hline 6. Keluwesan dinamis & • Kemampuan melakukan gerakan cepat. \\
\hline \multicolumn{2}{|l|}{ Faktor-faktor lain } \\
\hline 7. Koordinasi tubuh & $\begin{array}{l}\text { - Kemampuan mengkoordinasikan tindakan-tindakan serentak } \\
\text { dari bagian-bagnian tubuh yang berlainan. }\end{array}$ \\
\hline 8. Keseimbangan & $\begin{array}{l}\text { - Kemampuan mempertahankan keseimbangan, meskipun ada } \\
\text { kekuatan-kekuatan yang mengganggu keseimbangan itu. }\end{array}$ \\
\hline 9. Stamina & $\begin{array}{l}\text { - Kemampuan melanjutkan upaya maksimum yang menuntut } \\
\text { upaya yang diperpanjang sepanjang suatu kurun waktu. }\end{array}$ \\
\hline
\end{tabular}

\section{Kinerja, Kemampuan, Motivasi dan Peluang}

Menurut penelitian awal Blomberg, bahwa kinerja merupakan hasil dari kelipatan yang diperoleh antara kemampuan (ability) dan motivasi (motivation). Kemudian, Blomberg dan Pringle (1982:565) melengkapi persamaan kinerja tersebut dengan memasukkan peluang (opportunity) untuk mampu menjelaskan kinerja karyawan. Misalnya, persamaan tersebut menjadi Kinerja $=\mathrm{f}(\mathrm{A} \times \mathrm{M} \times \mathrm{O}$ (opportunity). Meskipun seorang individu bersedia dan mampu, mungkin masih terdapat rintangan yang menghambat kinerja seperti kurangnya faktor pendukung. Selama bertahun-tahun para peneliti berusaha memusatkan perhatian terhadap kepribadian. Ada 2 model yang diklasifikasikan dan banyak diterima dan mendapat perhatian, yaitu Myers Briggs Type Indicator (MBTI) dan The Big Five Model. MBTI adalah pendekatan yang sudah populer dan mengklasifikasikan sifat/ ciri individu sebagai penilaian umum yang disebut Myers-Briggs Type Indicator, sering juga disebut hanya singkatannya saja MBTI. 
Melalui penggunaan indikator-indikator MBTI, Briggs dan Myers (1980) mengajukan lebih dari 100 pertanyaan yang dijawab oleh orang-orang dari situasi dan latar belakang yang berbeda. Jika menjawab pertanyaan tersebut, maka anda memperoleh satu kesimpulan atau yang lain dari 4 dimensi. Kombinasi-kombinasi tersebut dapat dilihat pada Tabel 2 di bawah ini.

Tabel 2 Tipe Kepribadian MBTI (Myers-Briggs Types Indicators)

\begin{tabular}{|c|c|}
\hline Tipe & Penjelasan \\
\hline $\begin{array}{l}\text { INFJ (Introvert, Intuitive, Feeling, } \\
\text { Judgemental) }\end{array}$ & $\begin{array}{l}\text { Tenang, memiliki kepemimpinan yang kuat, peduli } \\
\text { terhadap yang lain, Banyak orang berhasil karena tekun, } \\
\text { jika menyukai sesuatu berusaha memperolehnya, Mereka } \\
\text { memegang teguh pendirian dengan dasar prinsip tidak } \\
\text { mengenal kompromi. }\end{array}$ \\
\hline $\begin{array}{l}\text { ESTP (Extrovert, Sensing, Thinking, } \\
\text { Perceptive) }\end{array}$ & $\begin{array}{l}\text { Terus terang, suatu saat tidak peduli. Orang seperti ini } \\
\text { mementingkan fakta, dan tidak mau khawatir dan } \\
\text { terburu-buru, Mereka senang apapun yang terjadi, } \\
\text { Mereka paling baik mengerjakan sesuatu yang nyata } \\
\text { apakah itu bisa dirakit atau tidak) }\end{array}$ \\
\hline $\begin{array}{l}\text { ISFP (Introvert, Sensing, Feeling, } \\
\text { Perceptive) }\end{array}$ & $\begin{array}{l}\text { Perasa, baik hati, sederhana, halus, bersahabat. Banyak } \\
\text { orang tidak menyukai dan tidak setuju dan akan } \\
\text { menhindarinya, Mereka adalah pengikut yang loyal, dan } \\
\text { sangat sering santai dalam melalukan atau mendapatkan } \\
\text { sesuatu. }\end{array}$ \\
\hline $\begin{array}{l}\text { ENTJ (Extrovert, Intuitive, } \\
\text { Thinking, Judgmental) }\end{array}$ & $\begin{array}{l}\text { - Hangat, bersahabat, jujur dan ingin menentukan; juga } \\
\text { sering ahli dalam segala hal dalam hal memberi alasan } \\
\text { dan ketelitian cara penyampaian, tetapi kadang-kadang } \\
\text { dapat melampaui perkiraan dari apa yang mampu } \\
\text { mereka kerjakan. }\end{array}$ \\
\hline
\end{tabular}

Organisasi/perusahaan besar di berbagai negara maju serta negara sedang berkembang seperti Indonesia sudah biasa melakukan pengukuran model MBTI terhadap anggotanya, terutama dalam melakukan seleksi/promosi jabatan. Namun, tidak ada bukti yang keras mendukung MBTI sebagai satu ukuran yang sahih (valid) dari kepribadian, walaupun pendapat ini tidak dapat mencegah penggunaan MBTI di berbagai organisasi/perusahaan besar tersebut.

Sementara itu, MBTI mungkin kekurangan bukti pendukung yang sahih. Hal itu tidak dapat dikatakan pada model 5 faktor dari kepribadian yang lajim disebut "Model Lima Besar". Dekade belakangan ini muncul sekumpulan riset yang mengesankan dan mendukung bahwa 5 dimensi kepribadian tersebut mendasari semua dimensi lain. Faktor 5 besar tersebut adalah sebagai berikut (1) Ekstraversi, yaitu mudah bergaul, banyak bicara, dan tegas; (2) Sifat menyenangkan, yaitu baik budi, kooperatif, dan mempercayai; (3) Sifat mendengarkan kata hati, yaitu bertanggungjawab, dapat diandalkan, tekun, dan berorientasi prestasi; (4) Kemantapan emosional, yaitu tenang, bergairah, terjamin (positif) lawan tegang, gelisah, murung, dan tak kokoh (negatif); (5) Keterbukaan terhadap pengalaman, yaitu imajinatif, peka secara artistik, dan intelektual.

Di samping itu, Barrick dan Mount (1991:10) memberikan suatu kerangka kepribadian yang mempersatukan riset mengenai 5 besar, juga telah menemukan hubungan yang penting antara dimensi kepribadian ini dan kinerja pada pekerjaan. Diperiksa 5 kategori jabatan, yaitu profesional (termasuk insinyur, arsitek, akuntan, pengacara), polisi, manajer, tenaga penjualan serta tenaga berketrampilan dan setengah berketrampilan. Kinerja pekerjaan didefinisikan dalam angka (ranking) kinerja untuk mengukur pencapaian (keluarahan) individu maupun kelompok dengan standar, keahlian pelatihan (kinerja selama program pelatihan), dan data personalia seperti tingkat gaji. Hasilnya menunjukkan bahwa sifat mendengarkan kata-hati meramalkan kinerja pekerjaan untuk kelima kelompok jabatan. Untuk dimensi-dimensi kepribadian lain, yang mampu diramal bergantung baik pada kriteria kinerja 
maupun kelompok jabatan. Misalnya, ekstraversi meramalkan kinerja dalam posisi manajerial dan penjualan. Ini masuk akan karena jabatan-jabatan ini memerlukan interaksi sosial yang cukup tinggi. Sama halnya dengan keterbukaan terhadap pengalaman dijumpai sebagai bagian penting dalam proses pelatihan, yang juga tampak logis. Apa yang tidak begitu logis adalah mengapa kemantapan emosional tidak dikaitkan dengan kinerja pekerjaan. Secara intuitif akan tampak bahwa orang-orang yang tenang dan merasa terjamin akan berbuat lebih baik pada hampir semua pekerjaan daripada orang-orang yang cemas dan merasa tidak kokoh. Para peneliti menyarakan bahwa jawabannya mungkin adalah bahwa hanya orang yang mempunyai skor yang cukup tinggi pada kemantapan emosional dapat mempertahankan pekerjaannya. Jadi kisaran di antara orang-orang yang dipelajari itu, yang semuanya dipekerjakan, dan variasi dimensinya akan cenderung sangat kecil dan tidak signifikan.

\section{Performa Kinerja dan Komitmen Organisasi Pekerja Profesional}

Human Capital a Key to Higher Market Value, demikian topik Business Finance akhir Desember (1999:15) sebagai penilaian terhadap performa kinerja yang dicapai industri di Amerika Serikat pada waktu itu, menilai bahwa sumbangan sumber daya manusia sangat penting dalam strategi organisasi dan sumbangan dari segenap karyawan untuk mencapai keunggulan bersaing sehingga dapat dikatakan bahwa sumber daya manusia memiliki pengaruh yang signifikan terhadap pencapaian kinerja organisasi. Laporan itu menyimpulkan bahwa pembaharuan praktik manajemen sumberdaya manusia dalam suatu organisasi dapat meningkatkan nilai pasar perusahaan tersebut sekitar 30\%. Begitu besarnya reaksi pasar terhadap kebijakan perusahaan di bidang sumber daya manusia yang dapat menambah keyakinan pada peningkatan nilai perusahaan maupun nilai barang dan jasa yang dihasilkan. Terminologi yang digunakan menjelaskan praktik yang demikian didasarkan pada praktikpraktik kerja dengan performa tinggi karena pencapaian kerja yang tinggi didasarkan pada tingginya pencapaian individu dan tingginya pencapaian organisasi.

Secara umum kelihatannya upaya yang dilakukan adalah meningkatkan komitmen organisasi yang terus-menerus berupa menyempurnakan dan memperbaiki pengetahuan, ketrampilan dan kemampuan para pekerja dalam organisasi, meningkatkan motivasi mereka, mengurangi kesalahan dalam pekerjaan, dan meningkatkan kualitas pekerja untuk menghindari penurunan performa.

Menurut Becker dan Gerhart (1996:785). Jika perusahaan memilih atau sama sekali tidak memilih performa kinerja tinggi, pada umumnya manajer sumber daya manusia harus memenuhinya guna menjamin dapat memiliki orang-orang yang berkualitas atau profesional untuk mempersiapkan pekerjaan yang perlu dikerjakan, meliputi semua kegiatan yang ada dalam organisasi. Berikut ini merupakan contoh praktik performa kinerja tinggi, yaitu mengarahkan diri sendiri bekerja dalam tim, rotasi pekerjaan, pelatihan ketrampilan tingkat tinggi, kelompok pemecah masalah, prosedur dan proses manajemen kualitas, mendorong perilaku kreatif dan inovatif, pengembangan keterlibatan para pekerja dan dalam pelatihan, mengimplementasikan semangat para pekerja, memberlakukan pemberian pengupahan berdasarkan performa pekerja, melatih dan menerapkan sistem mentor, berbagi sejumlah informasi yang signifikan serta menggunakan hasil survey sikap dan perilaku.

\section{Perilaku Kreatif dan Inovatif Pekerja Profesional}

Suatu organisasi secara terus-menerus mengembangkan dan menciptakan sesuatu dengan cara unik mengerjakan atau suatu pemecahan masalah. Kreatifitas adalah kemampuan mengkombinasikan gagasan-gagasan dengan cara yang unik dan profesional, atau membuat sesuatu yang tidak umum sehubungan dengan gagasan tersebut. Hasil dari proses penciptaan tersebut dibutuhkan untuk merubah suatu produk yang bermanfaat. Inovasi adalah proses melakukan suatu gagasan penciptaan dan memanfaatkannya menghasilkan suatu produk dan jasa atau metode kerja suatu kegiatan. Inovasi atau penemuan baru pada umumnya melalui ide atau gagasan yang secara kreatif dilakukan untuk menciptakan suatu produk atau jasa baru, atau memperbaharui suatu produk dan jasa yang telah ada, 
atau menciptakan suatu produk serial dalam rangka difrensiasi. Inovasi juga melakukan perubahan terhadap suatu sistem, metode dan proses kerja sehingga lebih efisien dan lebih efektif. Inovasi juga menyentuh penyempurnaan peralatan produksi menjadi lebih berdayaguna dan dan dapat digunakan mengerjakan pekerjaan yang beraneka.

Apabila seseorang profesional menyatakan suatu perubahan dalam organisasi untuk menjadi lebih kreatif, maka pengertiannya adalah mereka ingin merangsang dan memelihara inovasi. Kita mengetahui investasi sumber daya manusia profesional dalam melakukan penelitian dan pengembangan pada perusahaan-perusahaan global seperti Intel Corporation, Sony, Toyota, Airbus dan Boeing serta berbagai industri raksasa lainnya secara terus menerus merangsang dan memelihara inovasi yang berkelanjutan. Demikian halnya Intel Corporation terus menerus menyempurnakan desain dan kapasitas chip yang dihasilkan. Airbus dan Boeing terus-menerus menciptakan desain pesawat baru dan persaingan antar kedua pemimpin pasar industri pesawat ini masih melanjutkan pertarungannya menghasilkan pesawat serial terbaru. CocaCola tetap melakukan perubahan proses dan kemasan dari produknya. Microsoft tidak pernah berhenti melakukan inovasi, sedangkan Nokia semakin cepat mengadopsi teknologi baru untuk diimplementasikan pada produk-produk telepon seluler hasil produksinya. Industri otomotif seperti Toyota, Mistsubishi, dan Honda tidak ketinggalan dalam hal inovasi dengan pesaing globalnya dari AS seperti Crysler, Chevrolet, Ford, dan dari Eropa seperti Mercedes Benz, BMW, dan Audi. Ada 3 variabel yang menentukan dalam merangsang inovasi, sebagaimana terlihat pada Gambar 1 berikut ini. Oleh sebab itu, perusahaan-perusahaan yang lebih awal menyadari pentingnya investasi sumber daya manusia berupaya meningkatkan pengeluaran untuk investasi sumber daya manusia profesional di lingkungan organisasinya jika mereka diharapkan menjadi lebih kreatif dan inovatif, terutama dalam meningkatkan pendapatan perusahaan (revenue) dan membantu pertumbuhan perusahaan itu sendiri.

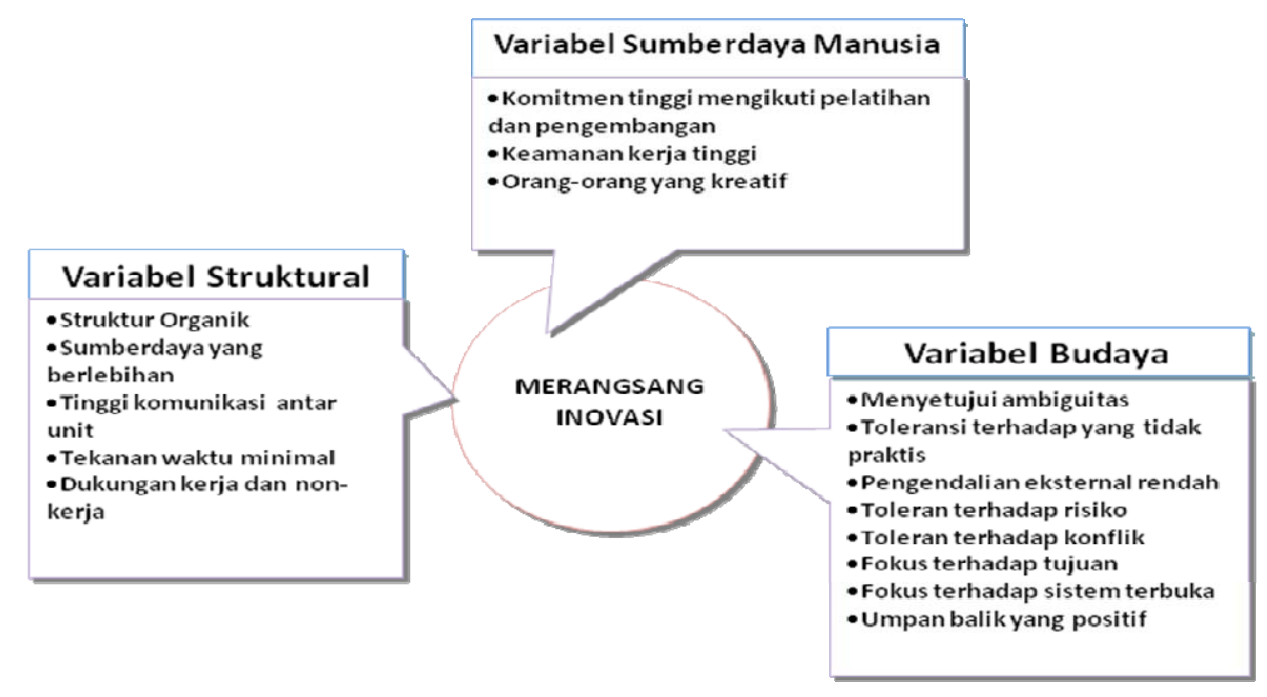

Gambar 1 Variabel-variabel yg Merangsang Kreatifitas dan Inovasi

\section{Upah, Tunjangan dan Kompensasi}

Pemberian kompensasi organisasional menurut Henderson (1994:15) dapat dalam berbagai jenis yang berbeda sebagai penghargaan dan tunjangan, seperti dasar penggajian dan pengupahan, tambahan gaji dan upah, pembayaran insentif, dan berbagai tunjangan dan pelayanan lainnya. Gaji bisa sama, namun penghasilan berbeda karena kalau ada pegawai yang terus-menerus performa kinerjanya rendah, jangan mengharapkan mendapat bonus, bahkan posisinya pun tetap disitu. 
Sebaliknya, jika seseorang secara terus-menerus mampu meningkatkan dan mempertahankan performa kinerjanya, maka manajer atasannya memberikan peningkatan nilai, yang berarti peningkatan bonus, rekomendasi promosi, termasuk memberi beasiswa program beasiswa Bachelor, Master ataupun Doktor. Masalahnya kemudian setelah selesai pendidikan, mereka cenderung mencari pekerjaan yang menguntungkan bagi mereka sehingga sebagian perusahaan hanya memberi 50\% dari biaya beasiswa, dan itupun dibuatkan semacam perjanjian atau kontrak.

Seorang manajer di AS tahun 2010 menghitung pendapatan pekerja di lingkungan perusahaan di mana ia bekerja. Seseorang mendapat pembayaran US\$.9 per jam dan juga menghitung seseorang mendapat US\$.350.000, atau Rp. 3,5 milyar setahun. Namun, dia lupa bahwa masih ada perusahaan yang membayar US \$ 5 per jam, yang artinya adalah kalau di Indonesia Rp 390.000 per hari. Kemudian, dia sangat terkejut melihat banyak pekerja profesional memperoleh pendapatan di atas jenjang manajer menengah. Berbagai faktor yang mempengaruhi kompensasi dan tunjangan, yaitu berbasis pekerjaan, jenis bisnis, padat modal atau padat karya, filsafat manajemen, lokasi kerja, profitabilitas perusahaan, besarnya perusahaan, masa kerja seseorang, dan prestasi kinerjanya. Banyak perusahaan yang menggunakan pendekatan alternatif pemberian kompensasi berdasarkan keahlian seseorang (skill-based-pay) yang merupakan sistem pengupahan sebagai penghargaan atas ketrampilan kerja dan kompetensi yang dipertunjukkan. Seorang ahli memberi komentar bagi mereka pekerja nonprofesional, ketrampilan rendah dan upah rendah, mengatakan hanya doa yang dapat membantu mereka. Adapun tantangan bagi para pekerja profesional di abad ke-21 antara lain perkembangan teknologi termasuk teknologi informasi dan komunikasi, kebijakan pemerintah, pasar global dan regional, perubahan ekonomi dan peluang kerja serta motivasi profesionalisme itu sendiri.

\section{Perkembangan Teknologi}

Teknologi itu sendiri selalu memerlukan perubahan. Peralatan dan mesin produk teknologi apapun selalu dituntut semakin efisien dan mampu sebagai motor akselerasi skala ekonomi sehingga memerlukan penyempurnaan dan perubahan yang terus-menerus. Kecepatan jalur industri dalam mengolah dan merakit produk mengalami kemajuan yang pesat sebagaimana organisasi berpikir mengganti tenaga manusia dengan robot. Penguasaan tehnologi baru yang terdiri dari mesin dan peralatan produk teknologi baru merupakan tuntutan yang harus karena ketrampilan yang dimiliki sekarang suatu saat tidak akan terpakai lagi atau menjadi hilang. Demikian halnya perkembangan teknologi informasi dan komunikasi yang demikian pesat sehingga para pekerja professional, selain terus-menerus meningkatkan pengetahuan bidang ketrampilannya sendiri, kelihatannya harus belajar dan mampu menggunakan teknologi informasi tersebut, misalnya program studi keuangan dan akuntansi sudah mutlak menambahkan manajemen sistem informasi dan praktik laboratorium komputer keuangan dan komputer akuntansi.

\section{Kebijakan Pemerintah}

Kebijaksanaan pemerintah suatu negara yang mendukung, yaitu segera melengkapi regulasi yang diperlukan untuk beradaptasi dan mengantisipasi perubahan, dan seberapa cepat pemerintah suatu negara untuk melakukan revisi peraturan perundang-undangan yang sangat menentukan dan berpengaruh pada organisasi, khususnya yang bergerak di bidang bisnis termasuk pekerja professional untuk memasuki pasar internasional, terutama birokrasi pengurusan perijinan, paspor, dan visa. Dengan demikian, sistem informasi tenaga kerja termasuk TKI profesional maupun non profesional sudah seharusnya ada dalam data base Departemen Luar Negeri dan Derpartemen Tenaga Kerja, yang terkait dari aspek legal dan perlindungan hokum dari keberadaan TKI di luar negeri sepenuhnya dapat dilindungi sesuai yang diamanatkan UUD 1945. 


\section{Pasar Global dan Regional}

Pasar semakin terbuka bagi mereka yang datang dari benua lain, dari seberang lautan. Kekuatan MNC dan perusahaan Transnasional memasuki pasar suatu negara, apalagi sudah dilandasi suatu perjanjian bersama seperti ACFTA (Asean-China Free Trade Agreement), NAFTA, AFTA, UE, APEC dan sebagainya, merupakan tantangan bagi tidak hanya organisasi/perusahaan lokal untuk mereformasi diri sekaligus memberikan peluang bagi para pekerja profesional memasuki pasar regional dan global tersebut. Para pekerja profesional tidak perlu belajar dari TKI yang non profesional untuk menyesuaikan diri dengan cepat dan radikal untuk memperoleh pengalaman yang berbeda dari negara asal, sekaligus belajar bekerja dengan berbagai orang lintas silang budaya. Biasanya yang menjadi kendala adalah selain kurang percaya diri, faktor penguasaan bahasa juga sangat penting serta kemauan untuk mempelajari budaya negara setempat di mana yang bersangkutan ditempatkan, baik sebagai tenaga kerja profesional, apalagi jika mendapat peluang manajer bertaraf global.

\section{Perubahan Ekonomi dengan Peluang Kerja}

Perubahan ekonomi dapat terjadi di negara maju sekalipun, apalagi pada negara sedang berkembang dan negara terbelakang yang sudah lama menderita. Situasi itu juga secara signifikan mempengaruhi organisasi/perusahaan besar, menengah maupun kecil. Justru yang kelihatannya dapat bertahan adalah perusahaan yang bergerak dalam memenuhi kebutuhan sehari-hari seperti ditunjukkan performa Wal-Mart di Amerika Serikat tahun 2009, yang diumumkan Fortune (www.fortune.com) dan IndustyWeek (www.industyweek.com) tahun 2010. Imbasnya adalah krisis pertama sekali mempengaruhi lembaga keuangan Bank dan Non-Bank, disusul industri properti dan otomotif yang mengalami penurunan pendapatan yang merosot tajam sehingga harus mengurangi sejumlah pekerja profesional maupun non profesional. Sedangkan industri makanan-minuman relatif mampu bertahan karena berlaku pameo bahwa orang hidup tidak berhenti makan dan minum. Keseluruhan kejadian tersebut mengancam kelangsungan eksistensi pekerja di perusahaan-perusahaan. Korban pertama biasanya para pekerja paroh-waktu, pekerja musiman, maupun pekerja yang tidak memiliki ketrampilan dan gaji rendah, dan karena status mereka pada umumnya tidak memperoleh kompensasi. Kalau kondisi semakin parah seperti yang dialami oleh Amerika Serikat 2009 lalu, maka para pekerja profesional dan para manajer juga dirumahkan dan ada sebagian yang langsung diberhentikan akibat perusahaan melakukan perampingan (downsizing). Seharusnya risiko semacam ini dapat diproteksi sejak awal, yaitu antara lain melalui asuransi sosial tenaga kerja, dana pensiun dan semacamnya untuk pribadi pekerja itu sendiri dan tidak mengandalkan perusahaan yang suatu saat dapat pailit dan tidak mampu melaksanakan kewajibannya. Di sisi lain, manakala situasi ekonomi kembali kepada titik keseimbangan baru, organisasi/perusahaan mengalami pertumbuhan, maka kebutuhan pekerja professional meningkat. Banyak peluang bagi pekerja profesional memilih perusahaan mana yang paling disukai sesuai preferensi masing-masing. Hal ini penting sebagai pertimbangan karena bekerja dan meniti karir dalam suatu perusahaan dalam waktu yang relatif lama.

\section{Motivasi Profesionalisme}

Pekerja profesional berbeda dengan mereka yang bukan profesional. Para profesional lebih mantap dan memiliki komitmen bekerja lebih lama dalam bidang keahliannya. Menurut Allen dan Katz (2002:54), bahwa mereka lebih loyal kepada profesi, ketimbang status sebagai pekerja. Untuk menguasai bidang mereka, secara regular memerlukan refreshing atau mempertajam pengetahuannya karena mereka lebih komitmen terhadap profesi daripada pekerjaan mereka yang mulai pukul 8.00 pagi hingga pukul 17.00 sore, 5 hari kerja dalam seminggu. Motivasi para profesional kelihatannya adalah pembayaran yang sesuai dan menyenangi pekerjaan mereka, sedangkan uang dan promosi adalah prioritas berikutnya. Kelihatannya sangat kontras dengan peluang kerja dengan jenjang yang lebih tinggi. 
Mereka lebih suka mengatasi masalah dengan mendapatkan solusi pemecahan. Atasan mereka memberi penghargaan atas pekerjaan mereka, yaitu pekerjaan itu sendiri. Seorang akuntan profesional lebih suka ditugaskan keluar melakukan audit keuangan perusahaan/industri, ketimbang diserahi jabatan sebagai kepala seksi di kantor. Demikian halnya seorang analis sistem informasi lebih senang mendapat tugas merancang bangun sistem informasi suatu perusahaan sedang, atau melakukan audit sistem perusahaan besar, ketimbang mengurusi hal-hal lain di kantor. Para profesional juga memerlukan dukungan nilai-nilai, di mana mereka menginginkan orang lain turut memikirkan apa yang sedang mereka kerjakan adalah penting. Hal ini mungkin benar bagi semua pekerja, namun bagi pekerja profesional cenderung lebih fokus kepada pekerjaan mereka sebagai pusat kepentingan hidup mereka. Sedangkan mereka yang pekerja non profesional tidak melupakan uang karena memiliki kepentingan lain di luar pekerjaan yang dapat mengkompensasi kebutuhan sosial yang tidak mereka temukan dalam pekerjaan mereka.

\section{SIMPULAN}

Setelah menelusuri keberadaan perilaku pekerja profesional secara teoritis maupun praktis serta peluang yang tersedia di hadapan mereka dalam mengarungi globalisasi abad ke-21, maka dirumuskan kesimpulan sebagai berikut. Belum ada definisi yang pasti yang dimaksud pekerja profesional, kecuali diidentifikasi mereka yang memiliki karakteristik berpendidikan dan memiliki ketrampilan yang lebih tinggi dari pekerja yang bukan profesional, bekerja pada organisasi/perusahaan sesuai dengan kompetensi pendidikan dan keahliannya tersebut. Mungkin hal ini sengaja dihindari sebagai solidaritas sosial terhadap mereka yang tidak tergolong profesional. Pekerja profesional tergolong mereka yang memiliki kemampuan intelektual, emosial, dan fisik yang prima. Pekerja profesional juga berpacu terus-menerus menambah pengetahuan dan ketrampilan serta kreatif dan inovatif dan yang selalu terus-menerus meningkatkan kompetensi diri, sehubungan dengan perkembangan teknologi, khususnya penggunaan teknologi informasi dan komunikasi yang merupakan penggerak ekonomi global dan regional dewasa ini karena pengetahuan dan ketampilan yang dimiliki sekarang bisa menjadi using dan hilang karena tidak terpakai di masa mendatang, paling tidak pasarnya menjadi berkurang secara terus-menerus.

Selain itu, pekerja profesional tidak luput dari ancaman resesi ekonomi global maupun regional yang memaksa mereka pada urutan berikut setelah non-profesional kehilangan pekerjaan sehingga setiap pekerja profesional tidak mengandalkan begitu saja program organisasi atas jaminan kelangsungan hidup mereka, melainkan mereka sendiri yang aktif mengatur adanya proteksi tersebut melalui program pribadi pada lembaga keuangan yang tersedia. Karena organisasi/perusahaan tempat mereka bekerja, walaupun cukup besar dan terkenal yang ada kalanya tidak mampu lagi memenuhi kewajiban normal jika sudah terperosok, pailit dan gulung tikar. Juga tidak menyarankan mereka menjadi "nomaden atau kutu loncat", kecuali kalau terpaksa dan itulah realitas perkembangan jaman. Selain para profesional yang lebih mementingkan profesi, padahal kebutuhan akan "uang” juga penting untuk kelangsungan hidup dan kebutuhan yang harus terus dipenuhi, dan juga menghargai nilai-nilai yang dianut serta tujuan hidup seseorang. Pekerja profesional muda seharusnya lebih mudah memasuki pasar global dan regional, ketimbang pekerja yang bukan profesional, jika didukung oleh rasa percaya diri, kemampuan berbahasa internasional serta didukung oleh regulasi pemerintah termasuk aspek legalitas dan perlindungan hukum. Hal ini tidak pernah bertentangan dengan moral nasionalisme karena justru pekerja di luar negeri menyumbang devisa bagi negaranya. Untuk mendukung pekerja professional Indonesia memasuki pasar global diperlukan percepatan regulasi, sistem dan mekanisme birokrasi yang lebih cepat dan murah serta memberikan jaminan aspek legal maupun perlindungan hukum yang memadai bagi tenaga kerja Indonesia di luar negeri. 
Rekomendasi yang diberikan dalam penelitian ini adalah sebagai berikut. Bagi Perguruan Tinggi sebagai penyelenggara tertinggi pendidikan dan ketrampilan, diharapkan memiliki dan menyelenggarakan program yang merangsang pekerja profesional untuk mempertajam performa pengetahuan dan ketrampilan untuk dapat berpacu sejajar dengan perkembangan ilmu pengetahuan dan teknologi, termasuk di dalamnya teknologi informasi dan mengatasi kendala bahasa dalam memperluas peluang memasuki pasar tenaga kerja regional maupun global. Berikutnya, bagi dunia industri dan perusahaan disarankan bahwa investasi sumber daya manusia adalah aset urutan pertama dalam neraca perusahaan, kendatipun tidak tertulis karena sifatnya tidak berwujud (intangible asset). Dengan demikian, perlu ditingkatkan dukungan biaya pendidikan dan pelatihan, dan penyesuaian sistem dan program imbalan berupa kompensasi dan tunjangan lainnya agar lebih wajar dengan melihat perbandingan secara regional, sekaligus memenuhi tuntutan kreatif dan inovatif dalam pekerjaannya serta mencapai performa kinerja yang tinggi secara berkesinambungan. Kepada Pemerintah RI, disarankan untuk mempercepat proses regulasi, meningkatkan upaya aspek legal dan perlindungan hukum yang dapat mendorong dan memberi peluang pekerja profesional memasuki pasar regional dan global, mengingat pertumbuhan angkatan kerja dan pengangguran yang cukup tinggi di Indonesia. Selain untuk meningkatkan penerimaan devisa dari sektor ketenagakerjaan, yang dapat dialokasikan bagi upaya peningkatan keterampilan para penganggur dan angkatan kerja baru untuk memasuki lapangan kerja baru.

\section{DAFTAR PUSTAKA}

Allen, T.T., and Katz, R. (2002). Managing technical professionals and organizations improving and sustaining the performance of organization, project teams, and individual contributors. Sloan Management Review, summer, p.54-55.

Anonym. (1999). Human capital a key to higher market value. Business Finance, December, p.15.

Ashkanasy, N.M., and Hartel, C.E.J. (2002). Emotional intelligence as a moderator of emotional and behavior reactions to job insecurity. Academic of Management Review, July, p.361-72.

Barrick, M.R., and Mount, M.K. (1991). The big five personaity dimension and job performance: a meta analysis. Personnel Psychology, vol.44, p.1-24.

Breckler, S.J. (1984). Empirical validation of affect, behavior, and cognition as distinct components of attitude. Journal of Personality and Social Psychology, May, p.1191-1205.

Becker, B., and Gerhart, B. (1996). The impact of human resource management on organization performance: progress and prospects. Academy of Management Journal, p.785.

Blumberg, M., and Pringle, C.D. (1982). The missing opportunity in organizational research: some implication for a theory of work performance. Academy of Management Review, October, p.565.

Bouchard Jr, T.J., Lykken, D.T., McCue, M., Segal, N.L., and Tellegen, A. (1990). Souces of human psyichological difference - the Minnesota study of twins reared apart. Science, October, p.223238.

Connor, P.E., and Becker, B.W. (1994). Personal values and management: What do we know and why don't we know more?. Journal of Management Inquiry, p.63-73. 
Crites, Jr, S.L., and Fabrigal, L.R. (1994). Measuring the affective and cognitive properties of attitudes: Conceptual and methodological issues. Personality and Social Psychology Bulletin, December, p.619-34.

Fishel, B. (1998). A new perspective: How to get the real story from attitude surveys. Training, February, p.91-94.

Henderson, R.I. (1994). Compensation management, $6^{\text {th }}$ ed., Upper Saddle River, New Jersey: Prentice Hall, p.3-24.

Keller, R.T. (1998). Job involvement and organization commitment as longitudinal predictors of job performance: a study of scientists and engineers. Journal of Applied Psychology, p.539-45.

LePine, J.A., Erez, A., and Johnson, D.E. (2002). The nature and dimensionality of organizational citizenship behavior: A critical review and meta-analysis. Journal Applied Psychology, February, p.52-65.

Rokeah, M., and Ball-Rokeah, S.J. (1989). Stability and change in american value priorities. American Psychologist, May, p.775-784.

Spector, P.E. (1982). Behavior in organization as a function of employee locus of control. Psychological Bulletin, May, p.482-97.

Staw, B.M., and Cummings, L.L. (1994). Research in organization behaviors, vol.6, Greenwich: JAI Press, CT.

The American Society for Personal Administrator. (1979). Personnel administrator, 606 North Washington Street, Alexandria, Virginia 22314, p.82-92. 